\title{
A comprehensive review of the nutritional, pharmacological, and industrial value of polyphenolic antioxidants found in onions
}

Meenakshi Sharma ${ }^{1}$, Arpitha Bandi ${ }^{2 *}$

${ }^{1}$ Department of Chemistry, Ranchi University, Ranchi, Jharkhand, India

${ }^{2}$ Department of Agriculture Biotechnology, Sardar Vallabhbhai Patel University of Agriculture and Technology, Meerut, Uttar Pradesh, India

\begin{abstract}
Onions are an excellent source of a variety of essential antioxidants, polyphenols, and other phytonutrients. These onions were used to enhance the meal's flavour and aroma. Additionally, onions have long been recognised for their ability to change food texture, making it more pleasant for eating. Among the most significant phenolic compounds identified in onions was Quercetin, which has been proven to be very helpful for maintaining good health by reducing the risk of heart disease, cancer, and a number of other severe conditions. Polyphenol extraction is essential for the effective usage and research of these phytochemicals. Previously, the extraction process was complicated by a variety of traditional methods, but with the aid of contemporary technology, the procedure was simplified. Additionally, it was found that red onions had greater health benefits than yellow onions, which were the most commonly used kind at the time. Apart from their health benefits, polyphenols were well recognised for their industrial use in dyeing, polymer manufacturing, and resin synthesis.
\end{abstract}

Keywords: onion, polyphenolics, antioxidants, extraction, health

\section{INTRODUCTION}

Allium cepa $\mathrm{L}$. ,Onion is one of the most valuable vegetable crops globally owing to its excellent taste and several health-beneficial properties. Onion bulbs are a rich source of antioxidants and sulfur-containing compounds, well-known for their potent anti-inflammatory effects, thereby helps in minimizing the chronic diseases, including cancer and diabetes [1]. According to Bolton, the onion name is given as a reasonable explanation where the onion mocks the campus bulletin called The Union. Onions usually produce chemical irritation called syn-prudential-s-oxide that stimulate the lachrymal gland in the eyes that cause tears. Onions are tolerant to cold and harsh conditions also, they can grow well in high temperatures and different growing environments. As a most cultivated crop, onion faces several breeding programme challenges. Onions are generally cross-pollinated, through insects and may sometimes result in genetic contamination [2]. There are several health benefits and medicinal properties of onions where they treat mouth sores, colds, headaches etc. Onions are packed with several vitamins and minerals; also, they contain low calories having reasonable amounts 
of Vitamin C and Vitamin B 9 and B 6 and are a good source of potassium promoting cellular function and proper muscle contraction. Onions maintain heart health due to Quercetin and anthocyanins, an antioxidant highly concentrated in onions. Onions fight against cancers due to the presence of sulphur compounds and flavonoid antioxidants. Also, onions aid in proper digestion due to inulin and fructo-oligosaccharides [3].

Along with the above essential factors and benefits of onions, polyphenols also are of primary importance due to their antioxidant properties and protection against certain diseases. These polyphenols contain flavonoids, phenolic acids, phenolic amides and lignans, which are also present in fruits, vegetables and grains. Out of these, the significant polyphenols observed in onions are flavonoids which include three diverse classes like flavonoids, fructans and organosulphur compounds [4].

As discussed, these polyphenols are associated with several health benefits by maintaining the blood sugar levels, thereby reducing the risk of type 2 diabetes in people consuming a high amount of polyphenols comparing to people who consume fewer polyphenols. Among polyphenols, anthocyanins provide an antidiabetic effect found in onions. Also, the continuous supplement of polyphenols proved to reduce the blood pressure and also LDL bad cholesterol levels increasing HDL good cholesterol [5]. Lower risk of heart disease is observed with high enterolactone levels obtained by lignan intake, a critical polyphenol. Proper intake of polyphenols is also known to help in reducing the risk of breast and prostate cancers. The flavonoids present in onions help improve blood flow to the brain and improve working conditions and memory of the brain. Polyphenols are also known to reduce blood clots, thereby promoting proper brain function, improved digestion, and protection against several cancers [6]. Along with onions, several other vegetables and fruits like carrots, potatoes, asparagus, apples, lemons, and pomegranates contain a good quantity of polyphenols. Sometimes higher polyphenols would result in kidney damage in rare cases [7]

It was observed that the total polyphenol content is more in yellow onions than red onions, making them very beneficial for consumption. In this review, we will concentrate mainly on the total polyphenols in onion, their presence in the peel and layers of onion and their composition, their extraction methodology, also concentrating on the health benefits and industrials uses of polyphenols[8].

\section{Extraction, Analysis, and Polyphenolic Composition of Onion Bulb and Skin}

Several publications were available on the extraction and analysis of the polyphenols in onions over the las few years. But the traditional methods were replaced by newly emerging advanced techniques. The conventional methods include sample preparation, separation, 
detection and identification, which are altered by modern techniques. Firstly, the extraction procedure should be understood properly along with the chemical nature of the substance, sample size, and the presence of interfering substances. Before starting the experiment, the time, temperature, and the number of extractions should be known because of their effect on the extraction yield. Additional steps were also performed to eliminate compounds like waxes, terpenes, fats etc., that were not required. Polyphenols can also possibly be extracted from fresh, dried or frozen plant samples [9].

\subsection{Traditional methods of extraction}

Polyphenol extraction is purely based on the solvent characteristics. Here the most commonly used solvents are acetone, diethyl ether, ethyl acetate etc. that are mixed in different proportions in water. These residues are considered harmful due to their effects on human health and their residual development in the final product, so it requires purification to obtain the result $[10]$.

The water bath method is the primary method for conventional extraction. This method of water bath extraction is done at temperatures ranging between 20 -so degrees; the more the time of water bath, high will be quality of the final product, i.e., polyphenol content. However, the use of higher temperatures above 70 degrees will decrease the polyphenol content because of their degradation. Also, the stability and quality of the extract are influenced by the $\mathrm{pH}$ of the medium. Therefore, $\mathrm{pH}$ between 4-5 is considered appropriate for polyphenol extraction in onions [11].

\subsection{Modern Extraction techniques}

Due to changes in temperature conditions and reduced quality of polyphenols by the influence of temperatures, specific new methods are adopted to reduce the quality issues. These modern techniques are pretty accurate and are used as alternative techniques for phenolic extractions [10].

\subsubsection{Microwave-Assisted Extraction}

This is the most effective and popular method, which reduces the quality losses and is very efficient in polyphenol extraction. Due to its ease and availability, this method was designed to work in two ways, pressurized (PMAE) microwave-assisted extraction and (SFMAE)solvent-free microwave-assisted extraction. This method eases the polyphenol extraction using less solvent. Most plants contain higher amounts of water, so this is an effective extraction tool. Low water content plants need longer to heat the microwave. The temperature of the heated plant in the microwave cannot exceed the boiling point of water (100 $\left.{ }^{\circ} \mathrm{C}\right)$. Microwave radiation consists of oscillation and magnetic fields. When the microwave 
electric field passes through water molecules, it forces water molecules to oscillate, resulting in friction between molecules and warming up. This method is the best so far and has less extraction time with energy-saving mode [12].

\subsubsection{Ultrasound-Assisted Extraction (UAE)}

UAE is beneficial to enhance bulk transfer, cell disorders, more enhanced penetration and capillary effects. Very high temperature in the UAE increases solubility, diffusivity, and pressure, which helps the waves penetrate the contents of the network and transportation in various organic and inorganic solvents. Ultrasonic probes and baths are the two most commonly used systems for extraction [13]. The cavitational effect of this wave facilitates the release of compounds that can be extracted and increase mass transportation by disturbing plant cell walls. Better Swelling increases mass transfer rate and results in increases extraction efficiency and decreases extraction time. Effect of ultrasonographic frequency, time, and the extraction intensity using different solvents were clear [14].

\section{Analysis of polyphenols}

In addition to organic solvent extraction under this technique, it can be applied to qualitative and quantitative analysis and for isolation and refining procedures[15, 16,17]. The primary polyphenols present in onions are quercetin, gallic acid, ferulic acid, and glycosides.

Quercetin, also known as a protector antioxidant, works with other antioxidants to provide significant health benefits and restore glutathione and vitamin C. It is helpful in relieving allergic reactions, reducing cancers, preventing infections and neurological disorders (Kim, Ko, \& Chung, 2019). It also works as a scavenger in removing the free radicals that damage the cells. A total of $300 \mathrm{mg} / \mathrm{g}$ of Quercetin is present in onions which is far more than any other vegetable. Gallic acid Certain therapeutic properties of gallic acid were recorded in gastrointestinal, metabolic and cardiovascular disorders. Several benefits of gallic acid recorded are anti-inflammatory, antineoplastic and antioxidant properties [17]. Ferulic acid is a potent antioxidant that reduces the damage caused by free radicals from pollution Infra-red radiation, which damages the skin cells. This compound was mainly useful for skin protection and used in several anti-ageing creams. This compound uniquely triggers other antioxidants [18]. To conduct the microscopic analysis for better understanding a dye known as DMACA reagent was used specific to polyphenols. Autoflourosence is used for localization of lignin and suberin for this DPBA (diphenylboric acid 2-aminoethyl ester) reagent was used so that the fluorescent signalling was enhanced [19].

\section{Major polyphenolic compounds}


There are several polyphenolic compounds available in nature primarily found in fruits and vegetables. These compounds were highly beneficial due to their antioxidant properties and medicinal values. Several phenolic compounds are available, but phenolic acids, flavonoids, stilbenes, tannins and lignans are the significant classes for these phenolic compounds

\subsection{Polyphenolic compounds in red and yellow onions}

Several reports indicated that onions are very healthy and beneficial for health. Therefore, more attention was drawn to the phenolic compounds of onions, which were essential for good health [20]. Generally, both red and yellow onions are instrumental in preparing dishes; in some parts, red onions are used for cooking purposes and white onions are used for garnishing. In India and some Asian countries, red onions play a significant role in cooking due to their flavour and color. But in the USA and few other countries, white onion was preferred over red onion due to its spice and high Sulphur content. Therefore, the availability of polyphenolic compounds was discussed by comparing the red and yellow onions [21].

It was observed that the total phenol content, flavonoid content and proanthocyanin content of yellow onions was slightly higher than that of the red onions. When compared within all the layers of the onions, the total phenol content was higher in yellow onions than red onions. Also, the flavonoid content from inner to outer layers of onions was higher in yellow onions and less in red onions. It was also observed that the highest flavonoid content was observed in the first layer of the onion and gradually reduced in the inner layers; the content is 7-fold in case of yellow onions and just 5-fold in case of red onions [22].

Proanthocyanin content in contrast to flavonoids and total polyphenolic content was higher in red onion and less in yellow onions, may be due to the red color of the onion. The anthocyanin pigment not only imparts color to the red onions but provide high antioxidant capacity. It was observed that the anthocyanin content in all the layers of red onions was steady without any maximum difference [23]. Thus it was concluded that the total phenolic content, flavonoid content and promising antioxidant activity was highest in case of yellow onions compared to red onions which is having high antioxidant properties. The reduction of the contents from outer to inner layers was observed in case of both the yellow and red onions. From our understanding it was advisable to prefer onions which are having maximum phenol, flavonoid content with antioxidant activity is very beneficial compared to antioxidant activity alone [22].

\section{Nutritional significance of onion polyphenols}




\subsection{Anti-cancer and anti-diabetic properties}

Apart from providing deep flavor, color and consistency to the food, onions are well known to protect from cancers. It was investigated that the regular use of onions would reduce bowel cancer. Along with several skin cancers, breast cancers colorectal cancer, aka bowel cancers, occupied third position as the most common cancer. It was proposed that the regular use of onions would reduce cancer risk [24]. A lot of attention was drawn regarding the clinical hypoglycaemic effects of onion due to its anti-diabetic properties. Diabetes was a heterogeneous group of disorders caused by several abnormalities especially in carbohydrates, proteins and lipids. It was proven from Environment reveals insights that consumption of fresh onions on daily basis would help to reduce the risk of type 1 and 2 diabetes showing positive impact on diabetes. It was observed that onions have a protective effect for diabetes by enhancing insulin resistance by encouraging multiplication of beta cells thereby increasing insulin secretion. These onion was proven to have several essential health benefits and can protect humans from health issues like cholesterol, cancers and diabetes [25]. As stated in Table 1 , many studies on onions were performed, and different literatures were reviewed to get a better knowledge of the uses and importance of onions in the treatment of several diseases. Onions have been shown to help mitigate the negative effects of cholesterol, diabetes, cancer, and post-cancer sickness, which explains why we should eat onions on a daily basis (Table 1). Table 3: Important studies on onion.

\begin{tabular}{|c|c|c|c|c|}
\hline Compounds & $\begin{array}{l}\text { Method of } \\
\text { assessment }\end{array}$ & Activities & Mechanism & $\begin{array}{l}\text { Referenc } \\
\text { e }\end{array}$ \\
\hline $\begin{array}{l}\text { Water extract } \\
\text { of peel }\end{array}$ & In-vitro & Anti-obesity & $\begin{array}{l}\text { Suppress } \\
\text { adipocyte } \\
\text { differentiation in } \\
\text { the cells 3T3-L1 } \\
\text { reduce the } \\
\text { expression of } \\
\text { adipogenesis } \\
\text { genes that were } \\
\text { related } \\
\text { adipocyte } \\
\text { differentiation and } \\
\text { lipolysis. }\end{array}$ & {$[26]$} \\
\hline
\end{tabular}




\begin{tabular}{|c|c|c|c|c|}
\hline Onion extract & $\begin{array}{l}\text { Human } \\
\text { intervention } \\
\text { studies }\end{array}$ & $\begin{array}{ll}\text { Control of } \\
\text { dyslipidemia }\end{array}$ & $\begin{array}{l}\text { Improve levels of } \\
\text { HDL, LDL, and } \\
\text { TC }\end{array}$ & [27] \\
\hline $\begin{array}{l}\text { Quercetin } \\
\text { Oxidation } \\
\text { Metabolite }\end{array}$ & & $\begin{array}{l}\text { Protection from } \\
\text { oxidative } \\
\text { stress }\end{array}$ & & [28] \\
\hline $\begin{array}{l}\text { Anti oxidant } \\
\text { activity, } \\
\text { Onion husk } \\
\text { ethanol } \\
\text { extract }\end{array}$ & $\begin{array}{l}\text { High performance } \\
\text { liquid } \\
\text { chromatography- } \\
\text { Mass spectrometry }\end{array}$ & Antiaging & $\begin{array}{l}\text { Gas } \\
\text { chromatography- } \\
\text { mass } \\
\text { spectrometry }\end{array}$ & [29] \\
\hline $\begin{array}{l}\text { Encapsulatio } \\
\mathrm{n} \text { on nano } \\
\text { chitosan, } \\
\text { Cancer } \\
\text { chemotherap } \\
\text { y }\end{array}$ & Nano chitosan & Anticancer & $\begin{array}{l}\text { Induction of } \\
\text { apoptosis }\end{array}$ & [30] \\
\hline $\begin{array}{l}\text { Sodium } \\
\text { chloride }\end{array}$ & $\begin{array}{l}\text { Hypertonic } \\
\text { solution, } \\
\text { Dehydration }\end{array}$ & Osmotic dehydration & $\begin{array}{l}\text { Osmoconcentratio } \\
\mathrm{n}, \\
\text { Level of } \\
\text { polyphenols }\end{array}$ & [31] \\
\hline $\begin{array}{l}\text { Onion } \\
\text { consumption }\end{array}$ & $\begin{array}{l}\text { Population based, } \\
\text { case-control } \\
\text { studies }\end{array}$ & Cancer control & Dietary intake & [32] \\
\hline $\begin{array}{l}\text { Gluconse } \\
\text { transporters }\end{array}$ & $\begin{array}{l}\text { Expression of } \\
\text { polyol pathway } \\
\text { enzymes }\end{array}$ & Diabetic nephropathy & $\begin{array}{l}\text { Dietary } \\
\text { interventions }\end{array}$ & [33] \\
\hline Steroids & $\begin{array}{l}\text { EGFR/ERK1/2/A } \\
\text { KT Signaling } \\
\text { Pathway }\end{array}$ & $\begin{array}{l}\text { Inhibit allergic } \\
\text { inflammation }\end{array}$ & $\begin{array}{l}\text { Thermo high } \\
\text { resolution gas } \\
\text { chromatography- } \\
\text { mass } \\
\text { spectrometer }\end{array}$ & [34] \\
\hline
\end{tabular}




\begin{tabular}{|c|c|c|c|c|}
\hline Doxorubicin & $\begin{array}{l}\text { MTT calorimetric } \\
\text { assay }\end{array}$ & $\begin{array}{l}\text { Adverse effects of } \\
\text { chemotherapy }\end{array}$ & $\begin{array}{l}\text { Western } \quad \text { Blot } \\
\text { analysis }\end{array}$ & [35] \\
\hline High fat diet & $\begin{array}{l}\text { Levels of LDL-C } \\
\text { and HDL-C }\end{array}$ & $\begin{array}{l}\text { Anti- obesity, } \\
\text { Hypolipidemic effect }\end{array}$ & $\begin{array}{l}\text { Body weight , } \\
\text { Obesit y }\end{array}$ & [36] \\
\hline $\begin{array}{l}\text { Aqueous and } \\
\text { ethanolic } \\
\text { extracts }\end{array}$ & High fat diet & Obseity & $\begin{array}{l}\text { High performance } \\
\text { liquid } \\
\text { chromatography }\end{array}$ & [37] \\
\hline Quercetin & $\begin{array}{l}\text { Hydrophyllic } \\
\text { serum fraction }\end{array}$ & Antioxidant capacity & $\begin{array}{l}\text { Biochemical } \\
\text { parameters }\end{array}$ & [38] \\
\hline Fatty liver & Serum levels & $\begin{array}{l}\text { nonalcoholic } \\
\text { steatohepatitis }\end{array}$ & Hepatic histology & [39] \\
\hline $\begin{array}{ll}\text { Red onion } \\
\text { scales }\end{array}$ & Streptozotocin & Diabetic nephropathy & $\begin{array}{l}\text { High performance } \\
\text { liquid } \\
\text { chromatography }\end{array}$ & [40] \\
\hline $\begin{array}{l}\text { Neutraceutica } \\
\text { ls potential }\end{array}$ & Oxidative stress & Hyperglycemia & $\begin{array}{l}\text { Tissue lipid } \\
\text { profile }\end{array}$ & [41] \\
\hline $\begin{array}{l}\text { Onion } \\
\text { extracts }\end{array}$ & Apoptosis & Colorectal cancers & Cytotoxic efffects & [42] \\
\hline Quecertin & $\begin{array}{l}\text { AMP- activated } \\
\text { protein kinase }\end{array}$ & $\begin{array}{l}\text { Remodelling } \\
\text { adipocytes, white to } \\
\text { brown }\end{array}$ & Browning effect & [43] \\
\hline Doxirubicin & $\begin{array}{l}\text { Controlled clinical } \\
\text { trails }\end{array}$ & Breast cancer & Insulin resistance & [44] \\
\hline Onion extract & $\begin{array}{l}\text { Pga 1 alpha } \\
\text { promote }\end{array}$ & Quercetin rich onion & DNA methylation & [45] \\
\hline $\begin{array}{l}\text { Onion } \\
\text { consumption }\end{array}$ & $\begin{array}{l}\text { Lipid mediator } \\
\text { levels }\end{array}$ & $\begin{array}{l}\text { hypercholesterole } \\
\text { mia }\end{array}$ & $\begin{array}{l}\text { Mass } \\
\text { spectrometry }\end{array}$ & [46] \\
\hline
\end{tabular}

\subsection{Antioxidant potential}

As discussed in table 2 several experiments are conducted and there are many theories regarding the antioxidant potential of onions. It was observed that the Indian red onions were proven to have high antioxidant capacity compared to other onions like yellow and white 
onions $[47,48]$. The outer layer of onions which is generally unutilized and wasted, contains higher proportions of anthocyanins and antioxidants. This outer papery layer can be an excellent source of beneficial antioxidants. This antioxidant property was adequately measured with the help of Trolox equivalent antioxidant capacity (TEAC), which then is used for calculating the amount of antioxidants present [49]. A report assessed and compared the antioxidant potentials in different onion cultivars belonging to Nigeria using an in-vitro assay technique. It was proven that the red onions have antioxidant potential over other cultivars, which is greater than $69 \%$, making red onions essential add-ons in our diet. These red onions contain the highest health-promoting potential factors when compared to others [50,51].

\section{Bioaccessibility and Bioavailability of Onion Polyphenolic antioxidants}

Polyphenolic antioxidants gained much importance in recent years due to their beautiful effects on human health and well-being. These compounds were known to treat several important diseases and health issues in our day-to-day life. A little consumption of onions regularly would help us improve several ailments due to their antioxidant activity. The wide range of antioxidants present in polyphenols is known to positively affect non-communicable diseases like cardiovascular diseases and diabetes [52]. Also, positive effects were observed on treating neurodegenerative diseases like Parkinson's and hunting diseases, but in early stages. The polyphenolic compounds present in onions reduce Obesity by promoting lipolysis so that bad cholesterol can be eliminated [53]. Interestingly, polyphenols interact with gut microbiota, thereby promoting healthy and good bacteria while preventing harmful bacteria. Also, these polyphenols increase the activity of probiotics by promoting their beneficial actions [54]. These polyphenols can be measured and isolated by volumetric titration. Permanganate, an oxidizing agent, was used to oxidize standard solutions, thereby creating a standard curve. Calorimetric measurements were also used to quantify polyphenolic contents.

New methods like biosensors were used to measure the polyphenolic contents. These measurements were adequately assessed with the help of HPLC and concluded. In general, the bioaccessibility of polyphenols is determined by their amount detected in the fruit or vegetable and released into the human body for easy access [55]. Polyphenols were wonderful natural phenols available from the phenylpropanoid pathway for the phenolic acids and shikimic way for tannins and analogues. Polyphenol Oxidase (PPO) is an enzyme that catalyzes o-diphenol oxidation to produce o-quinone. This is a quick polymerization of O-Quinon to produce black, brown or red polyphenolic pigments, which causes colouration of fruits and vegetables. Polyphenols from fresh samples were highly water-soluble and are obtained in large quantities 
[56]. Consuming standard servings of onion, coffee, wine, chocolate, legumes or tea may also contribute to about one gram of intake per day. Herbs, spices and beans also have the potential to be significant to supply certain polyphenols. These polyphenols were obtained from several fruits and vegetables[57]. Different cooking methods can change the polyphenol content. These polyphenols were better available in steamed vegetables than deep-fried vegetables because they can be destroyed by heat[58].

\section{Industrial applications}

In the Indian continent, pomegranate peel contains high tannins and other polyphenols, whereas juice, used in non-synthetic cloth colouring [47,59]. After being processed, the aim is to utilize plant residues from wine, olives (called pomacing) or pecan shells[48,60]. Especially in onion quercetin is one of the major polyphenolic compounds with several advantages and abundantly available in the skin and layers of onions. The availability of these compounds in different layers of onions are stable except for flavonoids [61,62]. The immense availability of polyphenols and its production would increase the preservation of the food by reducing its oxidation which is also an important property of polyphenols $[63,64]$.

\section{Conclusion and prospects:}

Not just a culinary plant, Onions are a common accompaniment in every Indian meal. These onions have gained much importance not only because of their flavour but also their colour, pungency, taste, and several health benefits. Different onion varieties were available throughout the world depending upon the people's usage like red, white, yellow. Out of these, red onions are a good source for curry making and white onions are usually used as salads. Several anti-bacterial, anti-diabetics, anti-cancerous and nutritious properties of onions made them a topic of interest to our study. These onions can grow in any temperature conditions except high chilling conditions, which results in stress and ultimately leads to death [65]. In our manuscript we have focussed mainly on the total polyphenols present in the onion and their importance. There are several health benefits associated with polyphenols which act as reducing agents such as vitamin $\mathrm{C}, \mathrm{E}$ and carotenoids protecting the body tissues against several ailments. These include anti-cancer activity, anti-ageing activity, anti-inflammation activity, lung-protective effect, neuroprotective effect, kidney protective effect and cardio protection. Among all the polyphenols in onion, Quercetin is one of the significant and dominatingpolyphenolsl presents. It is also quite helpful in preventing allergies, ageing, mood swings, cancers, asthma etc [66-70]. When compared red onion which is the primary consumable in India with yellow onion, it was observed that the flavonoids and other phenolic acids are more in the case of yellow onions. 
The amounts of these compounds were gradually reducing from outer layer to inner layers. In contrast, the antioxidant property which the primary and very beneficial property is high in case of red onion compared to the yellow onion and the quantity was very stable in all the layers of the onion. These antioxidant compounds are mostly available in large quantities in the unused peel of the onion. This high antioxidant content is due to the maximum amount of anthocyanin, the causative agent of red colour in the onions [20]. Several extraction methods, including traditional and advanced, were studied from different theories. It was proven that the advanced methods are less time-consuming and efficient in total polyphenol extraction.

Also, different activities and uses of polyphenols were discussed in the table 3 with several examples understanding their protection against harmful diseases. The antioxidant availability and properties were well understood, along with industrial applications and the areas of usage. Some research is going on to reduce the polyphenols losses caused by overcooking and frying. Also, the amount of the quercetin and other polyphenols and antioxidant content to be increased by tenfold by 2022 so that it would be more beneficial for consuming healthy fruits and vegetables and various health benefits are an added advantage [71-77].

References:

1. Cramer, C.S.; Mandal, S.; Sharma, S.; Nourbakhsh, S.S.; Goldman, I.; Guzman, I. Recent Advances in Onion Genetic Improvement. Agronomy-Basel 2021, 11, doi:10.3390/agronomy11030482.

2. Celano, R.; Docimo, T.; Piccinelli, A.L.; Gazzerro, P.; Tucci, M.; Di Sanzo, R.; Carabetta, S.; Campone, L.; Russo, M.; Rastrelli, L. Onion Peel: Turning a Food Waste into a Resource. Antioxidants 2021, 10, doi:10.3390/antiox10020304.

3. Santiago, B.; Calvo, A.A.; Gullon, B.; Feijoo, G.; Moreira, M.T.; Gonzalez-Garcia, S. Production of flavonol quercetin and fructooligosaccharides from onion (Allium cepa L.) waste: An environmental life cycle approach. Chemical Engineering Journal 2020, 392, doi:10.1016/j.cej.2019.123772.

4. Teshika, J.D.; Zakariyyah, A.M.; Zaynab, T.; Zengin, G.; Rengasamy, K.R.; Pandian, S.K.; Fawzi, M.M. Traditional and modern uses of onion bulb (Allium cepaL.): a systematic review. Critical Reviews in Food Science and Nutrition 2019, 59, S39-S70, doi:10.1080/10408398.2018.1499074.

5. Park, S.; Kim, D.H.; Lee, J.Y.; Ha, S.H.; Lim, S.H. Comparative Analysis of Two Flavonol Synthases from Different-Colored Onions Provides Insight into Flavonoid Biosynthesis. J Agric Food Chem 2017, 65, 5287-5298, doi:10.1021/acs.jafc.7b01036.

6. Sidhu, J.S.; Ali, M.; Al-Rashdan, A.; Ahmed, N. Onion (Allium cepa L.) is potentially a good source of important antioxidants. J. Food Sci. Technol.-Mysore 2019, 56, 18111819, doi:10.1007/s13197-019-03625-9.

7. Zhang, C.S.; Li, X.J.; Zhan, Z.X.; Cao, L.J.; Zeng, A.S.; Chang, G.J.; Liang, Y. Transcriptome Sequencing and Metabolism Analysis Reveals the role of Cyanidin Metabolism in Dark-red Onion (Allium cepa L.) Bulbs. Scientific Reports 2018, 8, doi:10.1038/s41598-018-32472-5. 
8. Prakash, S.B.; Mila, E. Nutritional and Therapeutic Potential of Garlic and Onion (Allium sp.). Current Nutrition \& Food Science 2016, 12, 190-199, doi:http://dx.doi.org/10.2174/1573401312666160608121954.

9. Gonzalez-de-Peredo, A.V.; Vazquez-Espinosa, M.; Espada-Bellido, E.; Carrera, C.; Ferreiro-Gonzalez, M.; Barbero, G.F.; Palma, M. Flavonol Composition and Antioxidant Activity of Onions (Allium cepa L.) Based on the Development of New Analytical Ultrasound-Assisted Extraction Methods. Antioxidants 2021, 10, doi:10.3390/antiox10020273.

10. Cozzolino, R.; Malorni, L.; Martignetti, A.; Picariello, G.; Siano, F.; Forte, G.; De Giulio, B. Comparative analysis of volatile profiles and phenolic compounds of Four Southern Italian onion (Allium cepa L.) Landraces. Journal of Food Composition and Analysis 2021, 101, doi:10.1016/j.jfca.2021.103990.

11. Zhou, Y.Y.; Li, C.; Feng, B.; Chen, B.; Jin, L.H.; Shen, Y.H. UPLC-ESI-MS/MS based identification and antioxidant, antibacterial, cytotoxic activities of aqueous extracts from storey onion (Allium cepa L. var. proliferurn Regel). Food Res Int 2020, 130, doi:10.1016/j.foodres.2019.108969.

12. Viera, V.B.; Piovesan, N.; Mello, R.D.; Barin, J.S.; Fogaca, A.D.; Bizzi, C.A.; Flores, E.M.D.; Costa, A.C.D.; Pereira, D.E.; Soares, J.K.B., et al. Ultrasonic _assisted extraction of phenolic compounds with evaluation of red onion skin (Allium cepa L.) antioxidant capacity. Journal of Culinary Science \& Technology 2021, 10.1080/15428052.2021.1910095, doi:10.1080/15428052.2021.1910095.

13. Ren, F.Y.; Nian, Y.Q.; Perussello, C.A. Effect of storage, food processing and novel extraction technologies on onions flavonoid content: A review. Food Res Int 2020, 132, doi:10.1016/j.foodres.2019.108953.

14. Li, Q.L.; Wang, Y.H.; Mai, Y.X.; Li, H.Y.; Wang, Z.; Xu, J.W.; He, X.J. Health Benefits of the Flavonoids from Onion: Constituents and Their Pronounced Antioxidant and Anti-neuroinflammatory Capacities. J Agric Food Chem 2020, 68, 799-807, doi:10.1021/acs.jafc.9b07418.

15. Piechowiak, T.; Grzelak-Blaszczyk, K.; Bonikowski, R.; Balawejder, M. Optimization of extraction process of antioxidant compounds from yellow onion skin and their use in functional bread production. LWT-Food Sci. Technol. 2020, 117, doi:10.1016/j.lwt.2019.108614.

16. Romo-Perez, M.L.; Weinert, C.H.; Haussler, M.; Egert, B.; Frechen, M.A.; Trierweiler, B.; Kulling, S.E.; Zorb, C. Metabolite profiling of onion landraces and the cold storage effect. Plant Physiology and Biochemistry 2020, 146, 428-437, doi:10.1016/j.plaphy.2019.11.007.

17. Pal, C.B.T.; Jadeja, G.C. Microwave-assisted deep eutectic solvent extraction of phenolic antioxidants from onion (Allium cepa L.) peel: a Box-Behnken design approach for optimization. J. Food Sci. Technol.-Mysore 2019, 56, 4211-4223, doi:10.1007/s13197-019-03891-7.

18. Munir, M.T.; Kheirkhah, H.; Baroutian, S.; Quek, S.Y.; Young, B.R. Subcritical water extraction of bioactive compounds from waste onion skin. Journal of Cleaner Production 2018, 183, 487-494, doi:10.1016/j.jclepro.2018.02.166.

19. Liu, Z.W.; Zeng, X.A.; Ngadi, M. Enhanced extraction of phenolic compounds from onion by pulsed electric field (PEF). J. Food Process Preserv. 2018, 42, doi:10.1111/jfpp.13755.

20. Kwak, J.-H.; Seo, J.M.; Kim, N.-H.; Arasu, M.V.; Kim, S.; Yoon, M.K.; Kim, S.-J. Variation of quercetin glycoside derivatives in three onion (Allium cepa L.) varieties. Saudi Journal of Biological Sciences 2017, 24, 1387-1391, doi:10.1016/j.sjbs.2016.05.014. 
21. Corell, L.; Armenta, S.; Esteve-Turrillas, F.A.; de la Guardia, M. Flavonoid determination in onion, chili and leek by hard cap espresso extraction and liquid chromatography with diode array detection. Microchemical Journal 2018, 140, 74-79, doi:10.1016/j.microc.2018.04.014.

22. Bottcher, C.; Krahmer, A.; Sturtz, M.; Widder, S.; Schulz, H. Effect of Cultivar and Cultivation Year on the Metabolite Profile of Onion Bulbs (Allium cepa L.). J Agric Food Chem 2018, 66, 3229-3238, doi:10.1021/acs.jafc.8b00254.

23. Kapoulas, N.; Koukounaras, A.; Ilic, Z.S. Nutritional quality of lettuce and onion as companion plants from organic and conventional production in north Greece. Scientia Horticulturae 2017, 219, 310-318, doi:10.1016/j.scienta.2017.03.027.

24. Roldán-Marín, E.; Sánchez-Moreno, C.; Lloría, R.; De Ancos, B.; Cano, M.P. Onion high-pressure processing: Flavonol content and antioxidant activity. LWT - Food Science and Technology 2009, 42, 835-841, doi:10.1016/j.lwt.2008.11.013.

25. Burri, S.C.M.; Ekholm, A.; Håkansson, Å.; Tornberg, E.; Rumpunen, K. Antioxidant capacity and major phenol compounds of horticultural plant materials not usually used. J Funct Foods 2017, 38, 119-127, doi:10.1016/j.jff.2017.09.003.

26. Yu, S.; Li, H.M.; Cui, T.H.; Cui, M.X.; Piao, C.X.; Wang, S.T.; Ju, M.; Liu, X.; Zhou, G.H.; Xu, H.Y., et al. Onion (Allium cepa L.) peel extract effects on 3T3-L1 adipocytes and high-fat diet-induced obese mice. Food Bioscience 2021, 41, doi:10.1016/j.fbio.2021.101019.

27. Huang, W.; Tang, G.; Zhang, L.Y.; Tao, J.; Wei, Z.Q. Effect of onion on blood lipid profile: A meta-analysis of randomized controlled trials. Food Science \& Nutrition 2021, 9, 3563-3572, doi:10.1002/fsn3.2309.

28. Fuentes, J.; de Camargo, A.C.; Atala, E.; Gotteland, M.; Olea-Azar, C.; Speisky, H. Quercetin Oxidation Metabolite Present in Onion Peel Protects Caco-2 Cells against the Oxidative Stress, NF-kappa B Activation, and Loss of Epithelial Barrier Function Induced by NSAIDs. $J$ Agric Food Chem 2021, 69, 2157-2167, doi:10.1021/acs.jafc.0c07085.

29. Chernukha, I.; Fedulova, L.; Vasilevskaya, E.; Kulikovskii, A.; Kupaeva, N.; Kotenkova, E. Antioxidant effect of ethanolic onion (Allium cepa) husk extract in ageing rats. Saudi Journal of Biological Sciences 2021, 28, 2877-2885, doi:10.1016/j.sjbs.2021.02.020.

30. Alzandi, A.A.; Naguib, D.M.; Abas, A.M. Onion Extract Encapsulated on Nano Chitosan: a Promising Anticancer Agent. J Gastrointest Cancer 2021, 10.1007/s 12029020-00561-2, doi:10.1007/s12029-020-00561-2.

31. Grzelak-Blaszczyk, K.; Milala, J.; Kolodziejczyk, K.; Sojka, M.; Czarnecki, A.; Kosmala, M.; Klewicki, R.; Fotschki, B.; Jurgonski, A.; Juskiewicz, J. Protocatechuic acid and quercetin glucosides in onions attenuate changes induced by high fat diet in rats. Food \& Function 2020, 11, 3585-3597, doi:10.1039/c9fo02633a.

32. Desai, G.; Schelske-Santos, M.; Nazario, C.M.; Rosario-Rosado, R.V.; MansillaRivera, I.; Ramirez-Marrero, F.; Nie, J.; Myneni, A.A.; Zhang, Z.F.; Freudenheim, J.L., et al. Onion and Garlic Intake and Breast Cancer, a Case-Control Study in Puerto Rico. Nutrition and Cancer-an International Journal 2020, 72, 791-800, doi:10.1080/01635581.2019.1651349.

33. Pradeep, S.R.; Barman, S.; Srinivasan, K. Attenuation of diabetic nephropathy by dietary fenugreek (Trigonella foenum-graecum) seeds and onion (Allium cepa) via suppression of glucose transporters and renin-angiotensin system. Nutrition 2019, 6768, doi:10.1016/j.nut.2019.06.024.

34. Khajah, M.A.; Orabi, K.Y.; Hawai, S.; Sary, H.G.; El-Hashim, A.Z. Onion bulb extract reduces colitis severity in mice via modulation of colonic inflammatory pathways and 
the apoptotic machinery. Journal of Ethnopharmacology 2019, 241, doi:10.1016/j.jep.2019.112008.

35. Aleksandar, P.; Dragana, M.C.; Nebojsa, J.; Biljana, N.; Natasa, S.; Branka, V.; Jelena, K.V. Wild edible onions - Allium flavum and Allium carinatum - successfully prevent adverse effects of chemotherapeutic drug doxorubicin. Biomedicine \& Pharmacotherapy 2019, 109, 2482-2491, doi:10.1016/j.biopha.2018.11.106.

36. Yang, C.; Li, L.H.; Yang, L.G.; Lu, H.; Wang, S.K.; Sun, G.J. Anti-obesity and Hypolipidemic effects of garlic oil and onion oil in rats fed a high-fat diet. Nutrition \& Metabolism 2018, 15, doi:10.1186/s12986-018-0275-x.

37. Sung, Y.Y.; Kim, D.S.; Kim, S.H.; Kim, H.K. Aqueous and ethanolic extracts of welsh onion, Allium fistulosum, attenuate high-fat diet-induced obesity. Bmc Complementary and Alternative Medicine 2018, 18, doi:10.1186/s12906-018-2152-6.

38. Grzelak-Blaszczyk, K.; Milala, J.; Kosmala, M.; Kolodziejczyk, K.; Sojka, M.; Czarnecki, A.; Klewicki, R.; Juskiewicz, J.; Fotschki, B.; Jurgonski, A. Onion quercetin monoglycosides alter microbial activity and increase antioxidant capacity. Journal of Nutritional Biochemistry 2018, 56, 81-88, doi:10.1016/j.jnutbio.2018.02.002.

39. Emamat, H.; Foroughi, F.; Eini-Zinab, H.; Hekmatdoost, A. The Effects of Onion Consumption on Prevention of Nonalcoholic Fatty Liver Disease. Indian Journal of Clinical Biochemistry 2018, 33, 75-80, doi:10.1007/s12291-017-0636-7.

40. Abouzed, T.K.; Contreras, M.D.M.; Sadek, K.M.; Shukry, M.; H. Abdelhady, D.; Gouda, W.M.; Abdo, W.; Nasr, N.E.; Mekky, R.H.; Segura-Carretero, A., et al. Red onion scales ameliorated streptozotocin-induced diabetes and diabetic nephropathy in Wistar rats in relation to their metabolite fingerprint. Diabetes Research and Clinical Practice 2018, 140, 253-264, doi:10.1016/j.diabres.2018.03.042.

41. Pradeep, S.R.; Srinivasan, K. Amelioration of oxidative stress by dietary fenugreek (Trigonella foenum-graecum L.) seeds is potentiated by onion (Allium cepa L.) in streptozotocin-induced diabetic rats. Applied Physiology Nutrition and Metabolism 2017, 42, 816-828, doi:10.1139/apnm-2016-0592.

42. Murayyan, A.I.; Manohar, C.M.; Hayward, G.; Neethirajan, S. Antiproliferative activity of Ontario grown onions against colorectal adenocarcinoma cells. Food Res Int 2017, 96, 12-18, doi:10.1016/j.foodres.2017.03.017.

43. Lee, S.G.; Parks, J.S.; Kang, H.W. Quercetin, a functional compound of onion peel, remodels white adipocytes to brown-like adipocytes. The Journal of Nutritional Biochemistry 2017, 42, 62-71, doi:10.1016/j.jnutbio.2016.12.018.

44. Jafarpour-Sadegh, F.; Montazeri, V.; Adili, A.; Esfehani, A.; Rashidi, M.R.; Pirouzpanah, S. Consumption of Fresh Yellow Onion Ameliorates Hyperglycemia and Insulin Resistance in Breast Cancer Patients During Doxorubicin-Based Chemotherapy: A Randomized Controlled Clinical Trial. Integrative Cancer Therapies 2017, 16, 276-289, doi:10.1177/1534735416656915.

45. Devarshi, P.P.; Jones, A.D.; Taylor, E.M.; Stefanska, B.; Henagan, T.M. Quercetin and Quercetin-Rich Red Onion Extract Alter Pgc-1 alpha Promoter Methylation and Splice Variant Expression. Ppar Research 2017, 2017, doi:10.1155/2017/3235693.

46. Colina-Coca, C.; Gonzalez-Pena, D.; de Ancos, B.; Sanchez-Moreno, C. Dietary onion ameliorates antioxidant defence, inflammatory response, and cardiovascular risk biomarkers in hypercholesterolemic Wistar rats. J Funct Foods 2017, 36, 300-309, doi:10.1016/j.jff.2017.07.014.

47. Sami, R.; Elhakem, A.; Alharbi, M.; Almatrafi, M.; Benajiba, N.; Mohamed, T.A.; Fikry, M.; Helal, M. In-Vitro Evaluation of the Antioxidant and Anti-Inflammatory Activity of Volatile Compounds and Minerals in Five Different Onion Varieties. Separations 2021, 8, doi:10.3390/separations 8050057. 
48. Sagar, N.A.; Pareek, S.; Gonzalez-Aguilar, G.A. Quantification of flavonoids, total phenols and antioxidant properties of onion skin: a comparative study of fifteen Indian cultivars. J. Food Sci. Technol.-Mysore 2020, 57, 2423-2432, doi:10.1007/s13197-02004277-w.

49. da Silva, M.G.R.; Skrt, M.; Komes, D.; Ulrih, N.P.; Pogacnik, L. Enhanced Yield of Bioactivities from Onion (Allium cepa L.) Skin and Their Antioxidant and Anti-alphaAmylase Activities. International Journal of Molecular Sciences 2020, 21, doi:10.3390/ijms21082909.

50. Piechowiak, T.; Balawejder, M. Onion skin extract as a protective agent against oxidative stress in Saccharomyces cerevisiae induced by cadmium. Journal of Food Biochemistry 2019, 43, doi:10.1111/jfbc.12872.

51. Wang, Y.Y.; Duan, X.; Ren, G.Y.; Liu, Y.H. Comparative study on the flavonoids extraction rate and antioxidant activity of onions treated by three different drying methods. Drying Technology 2019, 37, 245-252, doi:10.1080/07373937.2018.1482907.

52. Cattivelli, A.; Conte, A.; Martini, S.; Tagliazucchi, D. Influence of Cooking Methods on Onion Phenolic Compounds Bioaccessibility. Foods 2021, 10, doi:10.3390/foods10051023.

53. Lee, S.Y.; Lee, S.J.; Yim, D.G.; Hur, S.J. Changes in the Content and Bioavailability of Onion Quercetin and Grape Resveratrol During In Vitro Human Digestion. Foods 2020, 9, doi:10.3390/foods9060694.

54. Herranz, B.; Fernandez-Jalao, I.; Alvarez, M.D.; Quiles, A.; Sanchez-Moreno, C.; Hernando, I.; de Ancos, B. Phenolic compounds, microstructure and viscosity of onion and apple products subjected to in vitro gastrointestinal digestion. Innovative Food Science \& Emerging Technologies 2019, 51, 114-125, doi:10.1016/j.ifset.2018.05.014.

55. Ghatak, D.; Iyyaswami, R. Selective encapsulation of quercetin from dry onion peel crude extract in reassembled casein particles. Food and Bioproducts Processing 2019, 115, 100-109, doi:10.1016/j.fbp.2019.03.003.

56. Akdeniz, B.; Sumnu, G.; Sahin, S. Microencapsulation of phenolic compounds extracted from onion (Allium cepa) skin. J. Food Process Preserv. 2018, 42, doi:10.1111/jfpp.13648.

57. Sharma, K.; Ko, E.Y.; Assefa, A.D.; Ha, S.; Nile, S.H.; Lee, E.T.; Park, S.W. Temperature-dependent studies on the total phenolics, flavonoids, antioxidant activities, and sugar content in six onion varieties. Journal of Food and Drug Analysis 2015, 23, 243-252, doi:10.1016/j.jfda.2014.10.005.

58. S Bisen, P.; Emerald, M. Nutritional and therapeutic potential of garlic and onion (Allium sp.). Current Nutrition \& Food Science 2016, 12, 190-199.

59. Liguori, L.; Califano, R.; Albanese, D.; Raimo, F.; Crescitelli, A.; Di Matteo, M. Chemical Composition and Antioxidant Properties of Five White Onion (Allium cepa L.) Landraces. Journal of Food Quality 2017, 10.1155/2017/6873651, doi:10.1155/2017/6873651.

60. Ren, F.Y.; Reilly, K.; Gaffney, M.; Kerry, J.P.; Hossain, M.; Rai, D.K. Evaluation of polyphenolic content and antioxidant activity in two onion varieties grown under organic and conventional production systems. J Sci Food Agric 2017, 97, 2982-2990, doi:10.1002/jsfa.8138.

61. Fuentes, J.; Arias-Sante, M.F.; Atala, E.; Pastene, E.; Kogan, M.J.; Speisky, H. Low nanomolar concentrations of a quercetin oxidation product, which naturally occurs in onion peel, protect cells against oxidative damage. Food Chem 2020, 314, doi:10.1016/j.foodchem.2020.126166. 
62. Alu'datt, M.H.; Rababah, T.; Alhamad, M.N.; Johargy, A.; Gammoh, S.; Ereifej, K.; Almajoul, A.; Al-Karaki, G.; Kubow, S.; Ghozlan, K.A. Phenolic contents, in vitro antioxidant activities and biological properties, and HPLC profiles of free and conjugated phenolics extracted from onion, pomegranate, grape, and apple. International Journal of Food Properties 2017, 20, 1823-1837, doi:10.1080/10942912.2017.1349140.

63. Loredana, L.; Giuseppina, A.; Filomena, N.; Florinda, F.; Marisa, D.; Donatella, A. Biochemical, antioxidant properties and antimicrobial activity of different onion varieties in the Mediterranean area. Journal of Food Measurement and Characterization 2019, 13, 1232-1241, doi:10.1007/s11694-019-00038-2.

64. Ozcan, M.M.; Dogu, S.; Uslu, N. Effect of species on total phenol, antioxidant activity and phenolic compounds of different wild onion bulbs. Journal of Food Measurement and Characterization 2018, 12, 902-905, doi:10.1007/s11694-017-9705-0.

65. Lu, X.; Wang, J.; Al-Qadiri, H.M.; Ross, C.F.; Powers, J.R.; Tang, J.; Rasco, B.A. Determination of total phenolic content and antioxidant capacity of onion (Allium cepa) and shallot (Allium oschaninii) using infrared spectroscopy. Food Chem 2011, 129, 637-644, doi:10.1016/j.foodchem.2011.04.105.

66. Prior, R.L.; Fan, E.; Ji, H.; Howell, A.; Nio, C.; Payne, M.J.; Reed, J. Multi-laboratory validation of a standard method for quantifying proanthocyanidins in cranberry powders. J Sci Food Agric 2010, 90, 1473-1478, doi:10.1002/jsfa.3966.

67. Zill, E.H.; Vian, M.A.; Fabiano-Tixier, A.-S.; Elmaataoui, M.; Dangles, O.; Chemat, F. A remarkable influence of microwave extraction: Enhancement of antioxidant activity of extracted onion varieties. Food Chem 2011, 127, 1472-1480, doi:10.1016/j.foodchem.2011.01.112.

68. Kaushik, P.; Andújar, I.; Vilanova, S.; Plazas, M.; Gramazio, P.; Herraiz, F.J.; Brar, N.S.; Prohens, J. Breeding Vegetables with Increased Content in Bioactive Phenolic Acids. Molecules 2015, 20, 18464-18481, doi:10.3390/molecules201018464.

69. Brar, N.; Saini, D.; Kaushik, P.; Chauhan, J.; Kamboj, N. Directing for Higher Seed Production in Vegetables. In; 2019 ISBN 978-1-83881-222-5.

70. Sinha, S.; Sandhu, K.; Bisht, N.; Nailwal, T.; Saini, I.; Kaushik, P. Ascertaining the Paradigm of Secondary Metabolism Enhancement through Gene Level Modification in Therapeutic Plants. Journal of Young Pharmacists 2019, 11, 337-343, doi:10.5530/jyp.2019.11.70.

71. Priyanka, V.; Kumar, R.; Dhaliwal, I.; Kaushik, P. Germplasm Conservation: Instrumental in Agricultural Biodiversity-A Review. Sustainability 2021, 13, 6743, doi:10.3390/su13126743.

72. Kaushik, P.; Kumar, P.; Kumar, S. Enhancement of Chlorogenic Content of the Eggplant Fruit with Eggplant Hydroxycinnamoyl CoA-Quinate Transferase Gene via Novel Agroinfiltration Protocol. Pharmacognosy Magazine 2020, 16, 450, doi:10.4103/pm.pm_537_19.

73. Gupta, R.; Kaushik, P. Phyto-Potential of Allium Cepa and Allium Sativum; IntechOpen, 2021; ISBN 978-1-83969-609-1.

74. Kaushik, P.; Saini, D.K. Sequence Analysis and Homology Modelling of SmHQT Protein, a Key Player in Chlorogenic Acid Pathway of Eggplant; 2019; p. 599282;.

75. Brar, N.S.; Kaushik, P.; Dudi, B.S. Assessment of Natural Ageing Related PhysioBiochemical Changes in Onion Seed. Agriculture 2019, 9, 163, doi:10.3390/agriculture9080163.

76. Yadav, V.K.; Singh, R.; Jha, R.K.; Kaushik, P. Biochemical Variability of Eggplant Peel among Indian Cultivars. Indian Journal of Biochemistry and Biophysics (IJBB) 2020, 57, 634-637. 
77.. Sharma, M.; Kaushik, P. Biochemical Composition of Eggplant Fruits: A Review. Applied Sciences 2021, 11, 7078, doi:10.3390/app11157078. 